\title{
Physician-Patient Quality Time at the Clinic, Riyadh, Saudi Arabia
}

\author{
Khaled S. Albelall, Neamah A. Alubbad, Meshael Alboqmi, \\ Parthasarathy Jaganathan Parameaswari
}

KSMC, Riyadh, KSA

Email: neamah.a.alubbad@gmail.com

How to cite this paper: Albelall, K.S., Alubbad, N.A., Alboqmi, M. and Parameaswari, P.J. (2019) Physician-Patient Quality Time at the Clinic, Riyadh, Saudi Arabia. Open Access Library Journal, 6: e5197. https://doi.org/10.4236/oalib.1105197

Received: January 21, 2019

Accepted: February 15, 2019

Published: February 18, 2019

Copyright $\odot 2019$ by author(s) and Open Access Library Inc.

This work is licensed under the Creative Commons Attribution International License (CC BY 4.0).

http://creativecommons.org/licenses/by/4.0/

\section{(c) (i) Open Access}

\begin{abstract}
Purpose: The aim was to find the ideal time for the patients to know all the necessary information about their health from the doctor in the clinic and increase the performance of clinics in a better way. Methods: Observational study was conducted at the General Surgery and Cardiology clinics in general outpatient department of a tertiary care hospital in Riyadh, from Feb 2016 to Mar 2017. The time points of 202 randomly selected patients-Arrival time, Appointment time, Entry time \& Exit time were recorded using a standardized questionnaire and analyzed using SPSS 21. Results: From Cardiology department, $60(58.8 \%)$ from the forenoon clinic, $42(41.2 \%)$ post noon clinics and that of General surgery department, $76(76.0 \%)$ were from the forenoon and 24 $(24.0 \%)$ post noon clinics. The overall median waiting time was $29 \mathrm{mts}$ with interquartile range from $(11-51) \mathrm{mts}$ and a $95 \%$ confidence interval for mean between $(29$ - 41) mts for cardiology and for general surgery, it was $24 \mathrm{mts}$ with interquartile range from $6 \mathrm{mts}$ to $1 \mathrm{hr}$ and $4 \mathrm{mts}$. The median utilization time was $8 \mathrm{mts}$ with an interquartile range $(5-11) \mathrm{mts}$ for cardiology and $10 \mathrm{mts}$ with an interquartile range $(10-15) \mathrm{mts}$ for general surgery respectively. The Pearson's coefficient of correlation between entry time \& exit time was $r=$ $+0.96(\mathrm{P}<0.001)$ for Cardiology and $\mathrm{r}=+0.66(\mathrm{P}<0.001)$ for general surgery. Conclusions: This study was useful in assessing clinic efficiency and patient flow. A significant relationship was detected between allocated time and actual time spent by the patient in the clinic. This data helped in designing interventions that increase efficient use of resources and improve scheduling patterns.
\end{abstract}

\section{Subject Areas \\ Quality Patient Service}

\section{Keywords}

Time Allocated, Utilization Time, Waiting Time, Quality of Care 


\section{Introduction}

Inefficient use of time affects patient's appointments with their doctors, reducing their satisfaction, increasing their distress and increasing patient \& caregivers cost and in turn drains resources by disrupting clinic flow. There is also evidence that unfixed patient time with the doctor may also, directly or indirectly affect the recommended treatment of the patient. ThoDinh [1] study in Vietnam observed the waiting time was much higher among patients having health insurance compared to their counterparts. A study by Han et al. [2] also indicated that the number of patients that visit AnGiang Cardiovascular Hospital (An Giang Province) in the morning is higher than the afternoon. In Nigeria, 60\% patients had to wait 90 - 180 minutes for receiving examination [3]. In Ireland, a study conducted in an outpatient clinic showed that $50 \%$ of patients waited $60 \%$ for their appointment [4]. This issue is worse among countries with low provider-patient ratios [5]. Even in the USA, the average patient waiting time was from 60 minutes in Atlanta to 188 minutes in Michigan [6].

Quality health care is the care that uses resources effectively and efficiently. However, empirical studies of the use of resources and the costs of poor quality are rare. This is especially true for studies on the relationship between the use of clinic time for patient visits, patient flow (the movement of patients through the care setting), as well as costs to systems and to patients.

Evidence shows that patients are less likely to be dissatisfied if their waiting time is within 30 minutes [7]. Overseas studies have shown that patients are willing to wait an average of between 30 and 45 minutes to see a doctor [8]. Accordingly, patient waiting time is influenced by various factors, such as working procedure, patient overload and appointment schedule [9].

One vital component of patient time is the time patients spend in the clinic. However, this aspect of time has not been assessed in prior research primarily because it is difficult to objectively measure what transpires once a patient enters an examination room. In this study, we suggest a way to measure patient time and patient flow within the examination room. Specifically, we used one observational sheet, to record the time in the examination room.

The primary purpose of this study was to measure Patient wait time i.e. "Waiting time", Physician-patient interaction time in the examination room i.e. "Utilization time" and the discrepancy between the allocation time and utilization time. Subsequently, we examine the relationships among the various types of time. In addition to providing direct information on patient time in examination rooms, these data can also be used to evaluate efficiency in clinics and patient flow with limited physical resources.

\section{Methods}

This Observational study was conducted as a part of the process, quality, and outcomes related to patient-doctor communication and treatment decision making. From the Pilot data, we observed a Proportion of Patients who did not 
arrive between $(0$ - 15) mts of their appointment time was 69.6\% (P). Hence from 2 clinics each, minimum of 75 patients were Randomly [10] selected (new or follow-up) visiting outpatient department, i.e. 102 from Cardiology clinic and 100 from General Surgery clinic of a tertiary care hospital, Riyadh. The trained research assistant observed the patients once they entered the clinic till their exit from examination room and the reasons for their early \& delayed entry to clinic, early \& delayed exit from clinic were also obtained from patients. The data was collected between February 2016 and March 2017 and the four main parameters recorded were patient's arrival time, appointment time, entry time and exit time from the clinic in a structured form. Appointment times were determined a priori and the scheduled "allocation time" for Physicians in our clinical practice were $20 \mathrm{mts}$ for new patients and $15 \mathrm{mts}$ for the follow up cases. This study was approved by the Institutional Review Board with a waiver of consent. [IRB ref. No.: HRC-18-Jan16-01]

\subsection{Statistical Analysis}

The following measurement tools were calculated using the four parametersArrival time, Appointment time, Entry time \& Exit time of the patient as mentioned below:

\subsection{Measurement Tools for Clinical practice}

1) Difference between Entry Time and Appointment Time were presented as follows:

a) All "Negative values" were denoted as "Early Entry"

b) All "Positive values" were denoted as "Delayed Entry"

2) Difference between Exit Time and Entry Time measured the "Utilization Time"

\subsection{Measurement Tools for Patient Service}

1) Difference between Appointment Time and Arrival Time were presented as follows:

a) All "Negative values" were denoted as "Early Arrival"

b) All "Positive values" were denoted as "Late Arrival"

2) Difference between Exit Time and Entry Time were presented as follows:

a) All "Negative values" were denoted as "Out of Allocation Time"

b) All "Positive values" were denoted as "Within Allocation Time"

3) Difference between Entry Time and Arrival Time measures the "Waiting Time"

The data was analysed based on these measurement tools using SPSS 21.0 [11] and the outcome were presented as Descriptive Statistics-frequency, percentage, range, Mean, 95\% confidence interval of mean, Median $\left(\mathrm{P}_{50}\right)$, First Quartile $\left(\mathrm{P}_{25}\right)$ and Third Quartile $\left(\mathrm{P}_{75}\right)$. The values inside parenthesis represents percentages. Inferential statistics-Pearson's coefficient of correlation and tested at $5 \%$ 
level of significance. Univariate regression models were derived but found insignificant.

\section{Results}

The present study had $12(11.8 \%)$ new and 90 (88.2\%) follow-up patients from the cardiology department selected randomly constituted 60 (58.8\%) from the forenoon clinic, $42(41.2 \%)$ post noon clinics and that of $24(24.0 \%)$ new and 76 (76.0\%) follow-up patients from the General surgery department, 76 (76.0\%) were from the forenoon and 24 (24.0\%) post noon clinics.

Table 1 presents the descriptive statistics for the measurement tools of 102 patients. We observed $69(67.6 \%)$ who arrived earlier with a median time of 44 $\mathrm{mts}$ and interquartile range from $15 \mathrm{mts}$ to $1 \mathrm{hr} 13 \mathrm{mts}$ and 33 (32.4\%) arrived late after their appointment with a median time of $57 \mathrm{mts}$ interquartile range from 15 $\mathrm{mts}$ to $1 \mathrm{hr}$ and $38 \mathrm{mts}$. Thirty nine patients (38.2\%) had entered the clinic earlier to their appointment time with a median time of $30 \mathrm{mts}$ and interquartile range from $8 \mathrm{mts}$ to $1 \mathrm{hr} 2 \mathrm{mts}$ and $63(61.8 \%)$ delayed entry to their clinic with a median time of $36 \mathrm{mts}$ and interquartile range from $23 \mathrm{mts}$ to $1 \mathrm{hr}$ and $17 \mathrm{mts}$. Forty-eight $(47.1 \%)$ had an exit within their allocation time whose median time was $37 \mathrm{mts}$ and interquartile range from $16 \mathrm{mts}$ to $1 \mathrm{hr} 17 \mathrm{mts}$ and $54(52.9 \%)$ had an exit after allocation time from their clinic with a median time of $25 \mathrm{mts}$ and interquartile range from $11 \mathrm{mts}$ to $1 \mathrm{hr}$ and $1 \mathrm{mt}$. The overall median waiting time was $29 \mathrm{mts}$ with interquartile range from $11 \mathrm{mts}$ to $51 \mathrm{mts}$ and a $95 \%$ confidence for mean between $(29$ - 41) mts. The utilization time was observed with a median of $8 \mathrm{mts}$ and an interquartile range from $5 \mathrm{mts}$ to $11 \mathrm{mts}$ respectively. The $95 \%$ confidence interval for mean utilization time was $(7-12)$ mts. Figure 1 presents the Mean Waiting Time of Patients and Figure 2 their Mean Utilization Time.

In General surgery clinic, we observed $75(75.0 \%)$ patients arrived earlier with a median time of $31 \mathrm{mts}$ and interquartile range from $20 \mathrm{mts}$ to $1 \mathrm{hr} 20 \mathrm{mts}$ and $25(25.0 \%)$ arrived late for the appointment with a median time of $14 \mathrm{mts}$ interquartile range from $10 \mathrm{mts}$ to $1 \mathrm{hr}$ and $48 \mathrm{mts}$. Forty six patients $(46.0 \%) \mathrm{had}$ entered the clinic earlier to their appointment time with a median time of $15 \mathrm{mts}$ and interquartile range from $10 \mathrm{mts}$ to $48 \mathrm{mts}$ and 54 (54.0\%) delayed entry to their clinic with a median time of $10 \mathrm{mts}$ and interquartile range from 0 to 30 mts. Sixty eight $(68.0 \%)$ had an exit within their allocation time whose median time was $15 \mathrm{mts}$ and interquartile range from $5 \mathrm{mts}$ to $28 \mathrm{mts}$ and 32 (32.0\%) had an exit after allocation time from their clinic with a median time of $25 \mathrm{mts}$ and interquartile range from $8 \mathrm{mts}$ to $1 \mathrm{hr}$ and $10 \mathrm{mts}$. The overall median waiting time was $24 \mathrm{mts}$ with interquartile range from $6 \mathrm{mts}$ to $1 \mathrm{hr}$ and $4 \mathrm{mts}$. The utilization time was observed with a median of $10 \mathrm{mts}$ and an interquartile range from $10 \mathrm{mts}$ to $15 \mathrm{mts}$ respectively. The $95 \%$ confidence interval for mean utilization time was $(11-13) \mathrm{mts}$.

There were 36 new patients from 202 and the median waiting time for the Cardiology patients in the fore-noon clinic was $10 \mathrm{mts}$ with a $95 \%$ confidence 
Table 1. Descriptive Statistics of measurement tools for all patients.

\begin{tabular}{lcccc}
\hline $\begin{array}{l}\text { Patient's Time in Clinic } \\
\text { (hour: minutes) }\end{array}$ & N (\%) & $\begin{array}{c}\text { Percentiles } \\
25 / 50 / 75\end{array}$ & Mean & 95\% CI \\
\hline $\begin{array}{l}\text { Cardiology } \\
\text { 1) Early Arrival }\end{array}$ & $69(67.6)$ & $0: 15 / 0: 44 / 1: 13$ & $0: 49$ & $0: 39$ to $0: 58$ \\
2) Late Arrival & $33(32.4)$ & $0: 15 / 0: 57 / 1: 38$ & $1: 47$ & $0: 49$ to $2: 45$ \\
3) Early Entry & $39(38.2)$ & $0: 08 / 0: 30 / 1: 02$ & $0: 40$ & $0: 27$ to $0: 54$ \\
4) Delayed Entry & $63(61.8)$ & $0: 23 / 0: 36 / 1: 17$ & $1: 03$ & $0: 41$ to $1: 24$ \\
5) Exit within Allocation & $48(47.1)$ & $0: 16 / 0: 37 / 1: 17$ & $0: 55$ & $0: 36$ to $1: 14$ \\
6) Exit after Allocation & $54(52.9)$ & $0: 11 / 0: 25 / 1: 01$ & $0: 40$ & $0: 27$ to $0: 54$ \\
7) Waiting Time & 102 & $0: 11 / 0: 29 / 0: 51$ & $0: 35$ & $0: 29$ to $0: 41$ \\
8) Utilisation Time & 102 & $0: 05 / 0: 08 / 0: 11$ & $0: 10$ & $0: 07$ to $0: 12$ \\
& & & & \\
General Surgery & $75(75.0)$ & $0: 20 / 0: 04 / 1: 20$ & $1: 01$ & $0: 46$ to $1: 15$ \\
1) Early Arrival & $25(25.0)$ & $0: 10 / 0: 00 / 0: 46$ & $1: 25$ & $0: 10$ to $2: 39$ \\
2) Late Arrival & $46(46.0)$ & $0: 05 / 0: 08 / 0: 48$ & $0: 35$ & $0: 22$ to $0: 47$ \\
3) Early Entry & $54(54.0)$ & $0.06 / 0: 10 / 0: 30$ & $1: 00$ & $0: 20$ to $1: 39$ \\
4) Delayed Entry & $68(68.0)$ & $0: 31 / 0: 14 / 0: 28$ & $0: 28$ & $0: 19$ to $0: 37$ \\
5) Exit within Allocation & $32(32.0)$ & $0: 15 / 0: 10 / 1: 10$ & $0: 56$ & $0: 19$ to $1: 32$ \\
6) Exit after Allocation & $100(100.0)$ & $0: 15 / 0: 25 / 1: 04$ & $0: 40$ & $0: 32$ to $0: 49$ \\
7) Waiting Time & $100(100.0)$ & $0: 24 / 0: 10 / 0: 15$ & $0: 12$ & $0: 11$ to $0: 13$ \\
8) Utilisation Time & &
\end{tabular}

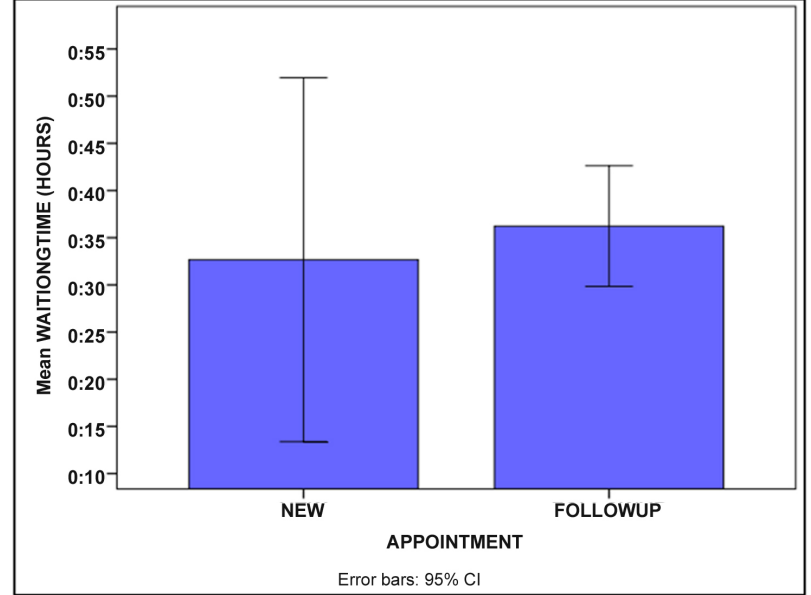

CARDIOLOGY CLINIC

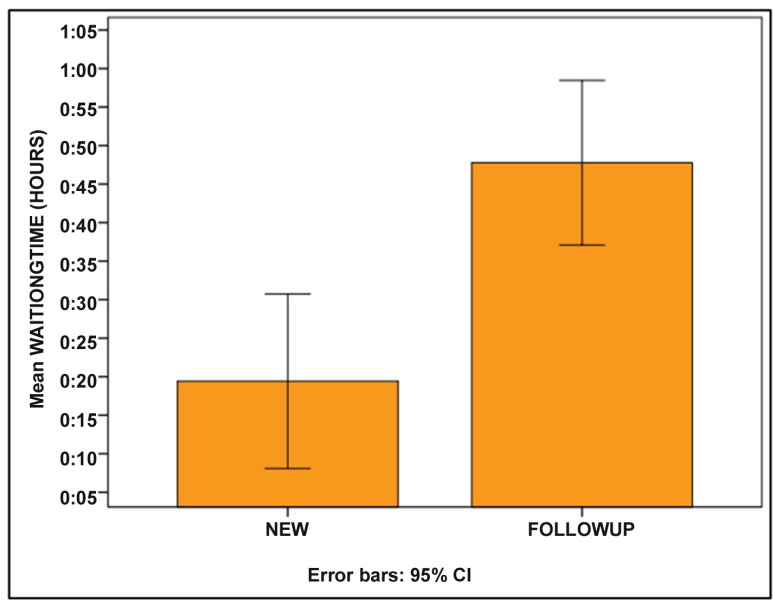

CENERAL SURGERY CLINIC

Figure 1. Mean waiting time of patients.

for mean between $(6-15) \mathrm{mts}$ and their median utilization time was $8 \mathrm{mts}$. The $95 \%$ confidence interval for mean utilization time was $(2-22) \mathrm{mts}$. The median waiting time from post noon clinic was $34 \mathrm{mts}$ and a $95 \%$ confidence for mean between (19 - 59) mts. Their median utilization time was $8 \mathrm{mts}$ and a $95 \%$ confidence for mean between $(7-15) \mathrm{mts}$. The median average waiting time for the surgery patients in the fore-noon clinic was $9 \mathrm{mts}$ and their utilization time was $15 \mathrm{mts}$. The $95 \%$ confidence interval for mean utilization time was (12 - 16) mts. The median waiting time in the post noon clinic was $11 \mathrm{mts}$ and their median utilization time was $15 \mathrm{mts}$. The $95 \%$ confidence interval for mean utilization time was $(12$ - 15) mts. From the 166 follow up patients from the cardiology forenoon clinic. The overall waiting time was $30 \mathrm{mts}$ and their median utilization 


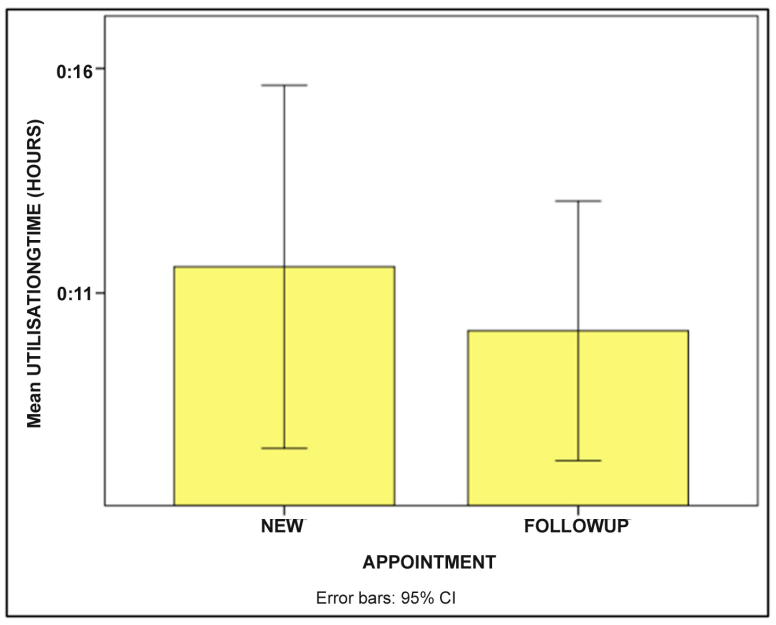

CARDIOLOGY CLINIC

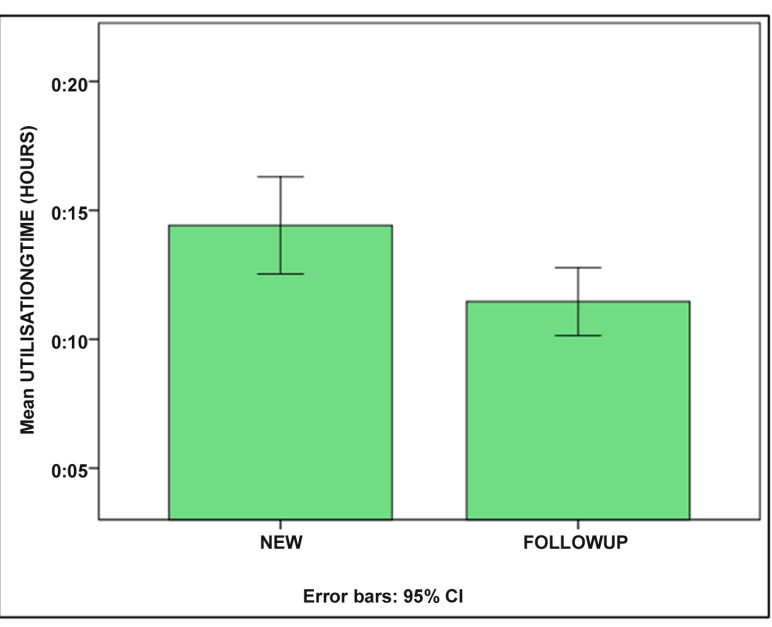

CENERAL SURGERY CLINIC

Figure 2. Mean utilisation time of patients.

time was $7 \mathrm{mts}$ with a mean of $9 \mathrm{mts}$ and a $95 \%$ confidence interval of $(7-11)$ mts. From the post noon clinic, the overall waiting time was $28 \mathrm{mts}$ and a $95 \%$ confidence for mean between $(26$ - 46) mts. Their median utilization time was 8 mts with a mean of $11 \mathrm{mts}$ and a $95 \%$ confidence interval of (5 - 17) mts. The overall waiting time in the surgery forenoon clinic was $43 \mathrm{mts}$ and their median utilization time was $10 \mathrm{mts}$ with a mean of $11 \mathrm{mts}$ and a $95 \%$ confidence interval of $10 \mathrm{mts}$ to $11 \mathrm{mts}$. From the post noon clinic, the overall waiting time was 36 $\mathrm{mts}$ and their median utilization time was $10 \mathrm{mts}$ with a mean of $11 \mathrm{mts}$ and a 95\% confidence interval of $5 \mathrm{mts}$ to $17 \mathrm{mts}$.

The Pearson's coefficient of correlation between Arrival time and exit time was statistically significant with $r=+0.77(\mathrm{P}<0.001)$, between entry time \& exit time was $r=+0.96(\mathrm{P}<0.001)$ and that of arrival time $\&$ entry time was $r=$ $+0.81(\mathrm{P}<0.001)$ for Cardiology and the correlation between Arrival time and exit time was statistically significant with $\mathrm{r}=+0.58(\mathrm{P}<0.001)$, between entry time \& exit time was $\mathrm{r}=+0.66(\mathrm{P}<0.001)$ and that of arrival time \& entry time was $r=+0.87(\mathrm{P}<0.001)$. The general linear model was formulated with these four time points but was observed to be insignificant.

Table 2 shows the reason for Arrival before $15 \mathrm{mts}$ of their appointment time as-transportation problem from residence, ensured themselves to be not late, decides to finish the appointment, they had an appointment at another clinic \& came from another hospital. Reasons for delayed entry was Patient came late to clinic, he arrived, left in between and returned, they were from outside Riyadh, went to wrong clinic, went to pharmacy to get medicine. The reasons for Exit time after (15 - 20) mts was previous patient took more time, miscommunication between patient \& doctor and patients argument with doctor about treatment.

\section{Discussion}

Inefficient use of time drains resources and disrupts clinic flow [12]. We have 
Table 2. Descriptive Statistics for the characteristics under study.

\begin{tabular}{|c|c|c|}
\hline Variable & $\begin{array}{c}\text { Cardiology } \\
\mathrm{N}=102(\%)\end{array}$ & $\begin{array}{c}\text { General Surgery } \\
\mathrm{N}=100(\%)\end{array}$ \\
\hline \multicolumn{3}{|l|}{ 1) Reason for Patients Arrival before $15 \mathrm{mts}$ of their appointment time: } \\
\hline - Transportation problem from residence & $19(18.6)$ & $10(10.0)$ \\
\hline - Patient ensures himself to be not late & $16(15.7)$ & $37(37.0)$ \\
\hline - Patient decides to finish his appointment & $7(6.9)$ & $18(18.0)$ \\
\hline - Patient came from another hospital & $3(2.9)$ & - \\
\hline 2) Patients arrival between 0 - 15 minutes of their appointment time & $1(1.0)$ & - \\
\hline - Yes & $31(30.4)$ & $73(73.0)$ \\
\hline $\begin{array}{l}\text { - No } \\
\text { 3) Reason for Patients delaved entry: }\end{array}$ & $71(69.6)$ & $27(27.0)$ \\
\hline - Patient came late to clinic & & \\
\hline - Patient arrived, left in between and returned & $9(8.8)$ & $14(14.0)$ \\
\hline - Patient is from outside Riyadh & $3(2.9)$ & - \\
\hline - Patient went to wrong clinic & $2(2.0)$ & - \\
\hline - Patient went to pharmacy to get medicine & $1(1.0)$ & - \\
\hline - Transportation Problem from residence & $1(1.0)$ & - \\
\hline 4) Exit time from clinic & $6(5.9)$ & - \\
\hline - Before allocation time & & $0(0)$ \\
\hline - Within allocation time & $22(21.6)$ & $0(0)$ \\
\hline - After allocation time & $76(74.5)$ & $92(92.0)$ \\
\hline \multicolumn{3}{|l|}{ 5) Reason for Exit time after $(15-20)$ minutes } \\
\hline - previous patient took more time & & \\
\hline - miscommunication between patient and doctor & - & $3(3.0)$ \\
\hline - patient argued with doctor about treatment & - & $3(3.0)$ \\
\hline
\end{tabular}

evaluated a method of measuring a major component of health care quality: patient flow and the utilisation of the examination room time. Time-focused research has consistently demonstrated that wait time significantly influences the emotional turmoil and health outcomes of patients with cancer [13] but in our study the overall median waiting time was $29 \mathrm{mts}$ and the median utilization time was $8 \mathrm{mts}$. The Quality assessment [14] was measured as mean discrepancy in the scheduled allocation time and the utilization time in cardiology clinic was $5 \mathrm{mts}$ with a $95 \%$ confidence interval 2 to $7 \mathrm{mts}$ which was statistically significant with $t=4.035(\mathrm{P}<0.001)$ and that of general surgery clinic, it was $4 \mathrm{mts}$ with a $95 \%$ confidence interval 2 to $5 \mathrm{mts}$ and statistically significant, $\mathrm{t}=7.332$ $(\mathrm{P}<0.001)$. The reasons for the waiting time and the time delay in the examination room were rectified. Evidence shows that patients are less likely to be dissatisfied if their waiting time is within 30 minutes [15]. Studies have also shown that the average consultation time in a primary care setting ranges between 10 to $15 \mathrm{mts}$ [16] [17], in the present study "Utilisation time" has confirmed the "Allocation time interval" for each patient to be adopted in our clinical practice and is in line with the local practice.

\section{Conclusion}

The actual time spent in face-to-face contact has been shown to be limited. Scheduling was important to ensure a smooth clinic process and to reduce wait- 
ing times. We were able to successfully obtain these measurements and find interesting results for overall system efficiency.

\section{Conflicts of Interest}

The authors declare no conflicts of interest regarding the publication of this paper.

\section{References}

[1] Tran, T.D., Nguyen, U.V., Minh Nong, V. and Tran, B.X. (2017) Patient Waiting Time in the Outpatient Clinic at a Central Surgical. 454.

[2] Nguyen, H.N.T., Nguyen, V.H.T. and Bui, T.M.H. (2012) Patient Waiting Time and Satisfaction of Patients in Outpatient Clinic, An Giang Cardiovascular Hospital.

[3] Oche, M.O. and Adamu, H. (2013) Determinants of Patient Waiting Time in the General Outpatient Department of a Tertiary Health Institution in North Western Nigeria. Annals of Medical and Health Science Research, 3, 588-592. https://doi.org/10.4103/2141-9248.122123

[4] McCarthy, K., McGee, H.M. and O'Boyle, C.A. (2000) Outpatient Clinic Waiting Times and Nonattendance as Indicators of Quality. Psychology, Health \& Medicine, 5, 287-293. https://doi.org/10.1080/713690194

[5] Mehra, P. (2016) Outpatient Clinic Waiting Time, Provider Communication Styles and Satisfaction with Healthcare in India. International Journal of Health Care Quality Assurance, 29, 759-777. https://doi.org/10.1108/IJHCQA-02-2016-0017

[6] dos Santos, L.M., Stewart, G. and Rosenberg, N.M. (1994) Pediatric Emergency Department Walk-Outs. Pediatric Emergency Care, 10, 76-78. https://doi.org/10.1097/00006565-199404000-00003

[7] McKinnon, K., Crofts, P.D., Rhiannon, E., et al. (2006) The Outpatient Experience: Results of a Patient Feedback Survey. International Journal of Health Care Quality Assurance Inc Leaders Health Serv., 11, 156-160. https://doi.org/10.1108/09526869810230858

[8] Bielen, F. and Demoulin, N. (2007) Waiting Time Influence on the SatisfactionLoyalty Relationship in Services. Managing Service Quality. An International Journal, 17, 174-193. https://doi.org/10.1108/09604520710735182

[9] Groome, L.J. and Mayeaux Jr., E.J. (2010) Decreasing Extremes in Patient Waiting Time. Quality Management in Healthcare, 19, 117-128. https://doi.org/10.1097/QMH.0b013e3181dafeac

[10] Betty, R.K. and Jonathan, A.C.S. (2003) Medical Statistics. Blackwell Publishing, 409.

[11] IBM Corp. (2012) IBM SPSS, Statistics for Windows, Version 21.0. IBM Corp., Armonk.

[12] Brown, M.L. and Yabroff, K.R. (2006) Economic Impact of Cancer in the United States. In: Schottenfeld, D. and Fraumeni Jr., J.F., Eds., Cancer Epidemiology and Prevention, Oxford University Press, Oxford, 202-213. https://doi.org/10.1093/acprof:oso/9780195149616.003.0012

[13] Gourdji, I., McVey, L. and Loiselle, C. (2003) Patients Satisfaction and Importance Ratings of Quality in an Outpatient Oncology Center. Journal of Nursing Care Quality, 18, 43-55. https://doi.org/10.1097/00001786-200301000-00007

[14] Buetow, S. and Roland, M. (1999) Clinical Governance: Bridging the Gap between 
Managerial and Clinical Approaches to Quality Care. Quality and Safety in Health Care, 8, 184. https://doi.org/10.1136/qshc.8.3.184

[15] McKinnon, K., Crofts, P.D., Rhiannon, E., et al. (2006) The Outpatient Experience: Results of a Patient Feedback Survey. International Journal of Health Care Qual Assur Inc Leaders Health Serv, 11, 156-160. https://doi.org/10.1108/09526869810230858

[16] Cape, J. (2002) Consultation Length, Patient-Estimated Consultation Length, and Satisfaction with the Consultation. British Journal of General Practice, 52, 1005 1006.

[17] Britt, H., Valenti, L. and Miller, G. (2002) Time for Care. Length of General Practice Consultations in Australia. Australian Family Physician, 31, 876-880. 